\title{
FINANSOWANIE PROJEKTÓW SEKTORA BIZNESU NA TERENACH POPRZEMYSŁOWYCH W MIEŚCIE W KONTEKŚCIE ROZWOJU LOKALNEGO
}

\section{Streszczenie}

Cel - Podjęta problematyka dotyczy współczesnego wyzwania miast (m.in. europejskich) w zakresie aktywizacji terenów poprzemysłowych, tj. kapitałochłonnych projektów sektora biznesu aktywizujących tereny poprzemysłowe w mieście w kontekście deprecjonowania negatywnego wpływu terenów poprzemysłowych na przestrzeń miasta, a także osiągania rozwoju lokalnego.

Metodyka badania - W ujęciu metodologicznym badanie zawiera kwerendę bibliograficzną w przedmiotowym zakresie badawczym.

Wynik - Przeprowadzone badania literaturowe przedstawiają kreowanie różnorodnych możliwości pozyskiwania kapitału przez sektor prywatny na inwestycyjnym rynku nieruchomości. Z punktu widzenia podmiotu sektora biznesu, dostępność kapitału warunkuje np.: jego forma prawna, zdolność kredytowa, etap procesu inwestycyjnego czy rodzaj nieruchomości stanowiącej przedmiot inwestycji.

Oryginalność/Wartość - Rozważania naukowe obejmują wyzwania współczesnych miast w zakresie ożywiania terenów poprzemysłowych. Jednocześnie odnoszą się do specyficznych uwarunkowań projektów lokalizowanych na terenach poprzemysłowych, m.in. wysokiej kapitałochłonności, a także czasochłonności i ich specyficznego ryzyka. W konsekwencji pojawia się konieczność różnicowania źródeł finansowania w obszarze inwestycji mających na celu ożywienie terenów poprzemysłowych.

Słowa kluczowe: teren poprzemysłowy, aktywizacja terenów poprzemysłowych, projekt sektora biznesu, finansowanie projektu

\section{FINANCING OF THE BUSINESS SECTOR PROJECTS ON BROWNFIELDS IN A CITY IN A CONTEXT OF THE LOCAL GROWTH}

\section{Summary}

Goal - The issue of the paper concerns contemporary challenge in cities (e. g. in european) connected with brownfields redevelopment ie. capital-intensive business sector projects which activate brownfields in a city in context of depreciation the negative influence of brownfields to space in a city and achievement local growth. Detailing it is included an identification of alternative sources of financing the buisness sector's brownfields redevelopment 
in a city. It's aim is to enhance possibilities of its diversification activating business sector to realise more brownfields redevelopment in a city.

Research methodology - Methodologically, research includes desk research connected with researching issues.

Score - Performed literature study shows the creation of variety possibilities of acquiring the capital by private sector on investigating real estate market, ie. eg. crowdfunding, corporate bonds, leasing, buy-back transactions, timesharing. Their availability in point of view of individual subject of business sector's conditiond, eg. legal form, creditworthiness, period of investment process, kind of real estate (including its way of using).

Originality/value - Scientific considerations including the contemporary city's challenge connected with importance of brownfield redevelopment shaped there. Simultaneously it is refered to specific conditions of projects located on brownfields, ei. eg. high capital-intensity and time-intensity and also their specific risk. In consequences, it is shaped necessity of differentation the funding sources of investments which are aimed at brownfield redevelopment

Key words: brownfield, brownfield redevelopment, business sector's project, financing the project

DOI: $10.15290 /$ wpewbmn3.2019.07

\section{Wprowadzenie}

Finansowanie to fundament działalności gospodarczej ${ }^{1}$. Wskazuje się, że kapitał stanowi wręcz „krwiobieg” przedsiębiorstw². Tym samym podstawą projektów na rynku nieruchomości są finanse ${ }^{3}$. W zakresie indywidualnych decyzji pozostaje wybór źródeł finansowania, w tym liczby ich rodzajów. Natomiast każdorazowo ukształtowana struktura wpływa na działalność podmiotu gospodarczego.

\section{Teren poprzemysłowy jako przedmiot aktywizacji w kontekście rozwoju lokalnego}

Dynamiczne otoczenie determinuje ciągłe zmiany, w jakich funkcjonują miasta $^{4}$. W ich zakresie wyróżnia się przeobrażenia o wymiarze kryzysogennym ${ }^{5}$.

\footnotetext{
${ }^{1} \mathrm{~J}$. Barburski, Kapitały własne jako podstawa bezpieczeństwa działalności gospodarczej na przykładzie przedsiębiorstw WIG20, „Finanse, Rynki Finansowe, Ubezpieczenia”, 2014, nr 67, s. 117.

${ }^{2}$ K. Janasz, Kapitat jako podstawa rozwoju przedsiębiorstwa, „Studia i Prace Wydziału Nauk Ekonomicznych i Zarządzania", 2008, nr 1, s. 72.

${ }^{3}$ P.N. Enzimuo, C.J. Onyeijaka, F.J. Emoh, Sources of real estate finance and their impact on property development in Nigeria: a case study of mortgage institutions in Lagos Metropolis, "British Journal of Environmental Research", 2014, no. 2 (2), s. 35.

${ }^{4}$ A. Drobniak, Urban resilience - nowa perspektywa badawcza rozwoju miast, [w:] Badania miejskie i regionalne. Doświadczenia i perspektywy, F. Kuźnik (red.), „Studia KPZK PAN”, 2013, t. 153, s. 205.
} 
W XX wieku zurbanizowaną, europejską tkankę miejską charakteryzowały istotne przekształcenia. Wyróżniono m.in. przestrzeń miast: polskich ${ }^{6}$, niemieckich, francuskich, brytyjskich ${ }^{7}$. W konsekwencji zostały ukształtowane tereny poprzemysłowe. Te natomiast cechuje problematyczny wymiar, gdyż hamują one rozwój lokalny ${ }^{8}$. Zaakcentowaniu podlegają tereny poprzemysłowe, ukształtowane w II połowie XX wieku, których kreację wtedy cechowały:

- masowość ${ }^{9}$ oraz

- $\operatorname{chaos}^{10}$.

W związku z powyższym wyodrębniono termin ugory przemysłowe ${ }^{11}$. Jednak ich specyfika dotyczy zarówno zagrożeń, jak i szans ${ }^{12}$. Powinno zatem mieć miejsce ich ożywianie ${ }^{13}$. Aktywizacja terenów poprzemysłowych może nastąpić pod wpływem realizacji projektów inwestycyjnych, jak również dzięki zmianie sposobu ich użytkowania ${ }^{14}$, m.in. na funkcję: mieszkaniową, biurową, handlową, rekreacyjną. Podkreśla się istotność wieloaspektowego zakresu osiąganych efektów, w tym: przestrzennych, ekonomicznych, społecznych ${ }^{15}$.

Ożywianie terenów poprzemysłowych może także determinować rozwój miasta ${ }^{16}$ oraz inteligentny wzrost miasta ${ }^{17}$.

${ }^{5}$ R. Wink, Regional Economic Resilience: Policy Experiences and Issues in Europe, "Raumforschung und Raumordnung", 2014, no. 72 (2), s. 60.

${ }^{6}$ D. Sikorski, Zmiany funkcjonalne terenów przemysłowych i poprzemysłowych we Wroctawiu po 1989 roku, [w:] Przekształcenia przestrzeni miejskiej Wrocławia. Ujęcie geograficzne, B. Namyślak, R. Szmytkie (red.), Wydawnictwo Uniwersytetu Wrocławskiego, Wrocław 2012, s. 33.

${ }^{7}$ A. Drobniak, Urban resilience and post-industrial city, [in:] Urban resilience concept and postindustrial cities in Europe, A. Drobniak (ed.), University Economics in Katowice, Katowice, 2014, s. 24.

${ }^{8}$ A. Maciejewska, A. Turek, Rewitalizacja obszarów zurbanizowanych i poprzemysłowych jako kierunek zrównoważonego rozwoju miast, [w:] Gospodarka przestrzenna w świetle wymagań strategii zrównoważonego rozwoju, A. Maciejewska (red.), „Studia KPZK PAN”, 2012, vol. 142, s. 81.

${ }^{9}$ K. Gasidło, Przeksztatcenia terenów i obiektów poprzemysłowych jako problem urbanistycznoarchitektoniczny województwa śląskiego, Zeszyty Naukowe Politechniki Śląskiej, nr 52, Gliwice 2013, s. 66.

${ }^{10}$ K. Gasidło, Przekształcenia terenów poprzemysłowych - efekty i perspektywy badań i działań, „Problemy Ekologii”, 2008, nr 12 (2), s. 76.

${ }^{11}$ K. Gasidło, Przekształcenia terenów i obiektów poprzemysłowych jako problem ..., op. cit., s. 66.

${ }^{12}$ E. Zagórska, L. Makowski, Zaangażowanie deweloperów w proces zagospodarowania terenów poprzemystowych, „Zarządzanie”, 2016, nr 24, t. 1, s. 152.

${ }^{13}$ D. Adams, C. de Sousa, Brownfield Development: A Comparison of North American and British Approaches, "Urban Studies", 2010, no. 47, s. 1.

${ }^{14}$ J. Koutský, O. Slach, T. Boruta, Restructuring Economies of Old Industrial Regions - Local Tradition, Global Trends In The Scale of Globalization, Think Globally, Act Locally, Change Individually in the 21st Century, University of Ostrava, Ostrava 2011, s. 168.

${ }^{15}$ S. Kaczmarek, Skuteczność procesu rewitalizacji. Uwarunkowania, mierniki, perspektywy, „Studia Miejskie”, 2015, nr 17, s. 29.

${ }^{16}$ D. Grimski, U. Ferber, Urban Brownfields in Europe, "Land Contamination Reclamation", 2001, vol. 9, no. 1, s. 143.

17 S.A. Sutton, Urban Revitalization in the United States: Policies and Practices, Columbia University, 2008, s. 44. 


\section{Kapitałochłonność projektów sektora biznesu aktywizujących tereny poprzemysłowe}

Wśród podmiotów aktywizujących tereny poprzemysłowe wymienia się przedstawicieli sektora publicznego ${ }^{18}$, a także prywatnego, w tym biznesu ${ }^{19}$. Zachęca się do nawiązywania współpracy między sektorem publicznym a sektorem biznesu ${ }^{20}$. Sektor publiczny nie jest zdolny samodzielnie zajmować się ożywianiem terenów poprzemysłowych. W przeciwieństwie do niego, sektor prywatny dysponuje np. nowszymi technologiami. Mobilizowanie sektora biznesu powinno być zatem wspierane przez sektor publiczny ${ }^{21}$.

Do podmiotów sektora biznesu można zaliczyć dewelopera. Uczestniczy on $\mathrm{w}$ procesie gospodarowania przestrzenią miasta ${ }^{22}$. Projekty wspomnianych podmiotów sektora biznesu mogą polegać na zmianie sposobu użytkowania terenów poprzemysłowych ${ }^{23}$ na mieszkaniowy i komercyjny, poprawiając jakość $\dot{z ̇ y c i a}^{24}$. Sektor biznesu wykazuje zdolność realizowania projektów ożywiających tereny poprzemysłowe o wieloaspektowym zakresie efektów ${ }^{25}$.

Warto zwrócić uwagę na: kapitałochłonnośćc ${ }^{26}$, niską przejrzystośćc ${ }^{27}$ i niehomogeniczność ${ }^{28}$ rynku nieruchomości. W przypadku terenów poprzemysłowych (jako lokalizacji projektów sektora biznesu) szczególnie akcentuje się czasoi kapitałochłonność. W konsekwencji istotna jest identyfikacja potencjalnych źródeł finansowania projektów sektora biznesu, aktywizujących tereny poprzemysłowe w mieście. Ponadto, znaczące jest wtedy dokonywanie zdywersyfikowanego finansowania ${ }^{29}$.

Ze względu na ekonomiczny potencjał terenów poprzemysłowych wyróżnia się np. tereny typu $\mathrm{B}^{30}$. Są one interesujące badawczo $\mathrm{w}$ zakresie kreowanego

\footnotetext{
${ }^{18}$ E. Zagórska, L. Makowski, Zaangażowanie deweloperów ..., op. cit., s. 153.

${ }^{19}$ Ibidem, s. 154.

${ }^{20}$ A. Sztando, Gospodarcza płaszczyzna programów rewitalizacji obszarów miejskich, „Studia Miejskie”, 2010, t. 1, s. 308.

${ }^{21}$ B. Cobârzan, Overview of financial and non-financial incentives for brownfield redevelopment, "Transylvanian Review of Administrative Sciences", 2008, no. 23, E, s. 16.

${ }^{22} \mathrm{M}$. Gostkowska-Drzewicka, Model funkcjonowania rynku deweloperskiego, „Zarządzanie i Finanse", 2012, r. 10, nr 2, cz. 1, s. 50.

${ }^{23}$ J. Koutský, O. Slach, T. Boruta, Restructuring Economies of Old ..., op. cit., s. 168.

${ }^{24}$ R. Kraske, Private Investment in Brownfield Redevelopment in the Greater Philadelphia Area: A Case-Study Analysis, "Master of Envionmental Studies Capstone Projects", 2007, no. 14, s. 6.

${ }^{25} \mathrm{~K}$. Śmietana, Idea odpowiedzialnych inwestycji $w$ nieruchomości $w$ działalności deweloperskiej, "Journal of Management and Finance", 2014, no. 12 (4), s. 433.

${ }^{26}$ M. Gostkowska-Drzewicka, Obligacje $w$ strukturze kapitatu przedsiębiorstw deweloperskich notowanych na GPW, „Finanse, Rynki Finansowe, Ubezpieczenia”, 2014, nr 65, s. 95.

27 E. Kucharska-Stasiak, Pomiar wartości na gruncie ekonomii - reperkusje dla wyceny nieruchomości, "Journal of the Polish Real Estate Scientific Society", 2011, no. 19(1), s. 14.

${ }^{28} \mathrm{R}$. Cellmer, Spatial analysis of local real estate market activity - the example of the city of Olsztyn, [in:] Topical issues in the valuation and application of market value, Polish Real Estate Scientific Society, Olsztyn 2012, s. 77.

${ }^{29}$ E. Zagórska, L. Makowski, Zaangażowanie deweloperów ..., op. cit., s. 164.

${ }^{30}$ The Future lies on brownfields, Federal Environmental Agency, Dessau 2005, s. 8.
} 
potencjału inwestycyjnego, zwłaszcza w kontekście nawiązywanego dialogu między sektorem publicznym i prywatnym ${ }^{31}$. Charakteryzuje je przeciętny poziom kosztów i potencjał generowania korzyści, choć prawdopodobnie nieprzekraczających kosztów. Za kluczową uznaje się koncepcję projektu inwestycyjnego - w jakim stopniu wykreuje jego wartość. W związku z powyższym, podkreśla się znaczenie doboru źródeł finansowania inwestycji. Co więcej, podkreśla się zasadność dokonywania wsparcia ze strony sektora publicznego dla sektora biznesu wobec lokalizowania projektów na terenach poprzemysłowych, z wyróżnieniem inwestycji typu $\mathrm{B}^{32}$.

\section{Źródła finansowania projektów sektora biznesu na inwestycyjnym rynku nieruchomości}

Dotychczas podstawowym źródłem finansowania inwestycji prywatnych na rynku nieruchomości był kredyt. Finansowanie nieruchomości w Polsce następowało wówczas $\mathrm{z}$ udziałem banków hipotecznych i uniwersalnych ${ }^{33}$. Z racji kapitałochłonności projektów akcentowaniu podlega poszerzanie źródeł finansowania poza klasyczny kredyt hipoteczny.

Wśród współczesnych, alternatywnych źródeł finansowania projektów sektora biznesu na rynku nieruchomości wskazuje się m.in.: crowdfunding, obligacje korporacyjne, project finance, leasing, metodę buy-back i timesharing.

Crowdfunding określa się jako finansowanie społecznościowe, a przez społeczność należy rozumieć tzw. tłum, w zakresie którego występują niepowiązane osoby. W tym przypadku pozyskiwanie finansowania odbywa się przez internet $^{34}$, stąd określenie wręcz e-tłumu ${ }^{35}$. Crowdfunding nieruchomości (RE-CF) pojawił się na świecie około I dekady XXI wieku, a w Polsce od około 2015 roku $^{36}$. Wiąże się on ze zbiorowym inwestowaniem w nieruchomość poprzez platformę crowdfundingową ${ }^{37}$. Możliwe jest poszerzanie grona inwestorów ${ }^{38}$. Inwestor, np. deweloper, promuje podejmowany projekt na rynku nieruchomości na specjalnej platformie, oferując np. udziały w tym projekcie ${ }^{39}$.

${ }^{31}$ The Management of Redevelopment. A Guidance Note, The World Bank, 2010, s. 3.

${ }^{32}$ The Future lies ..., op. cit., s. 8.

33 I.D. Czechowska, Finansowanie za pomoca kredytu bankowego wobec braku stabilności finansowej a problem bezpieczeństwa konsumenta, „Annales. Etyka w życiu gospodarczym”, 2010, nr 13(1), s. 241

${ }^{34}$ M. Gostkowska-Drzewicka, Crowdfunding jako źródło finansowania inwestycji $w$ nieruchomości, „Finanse, Rynki Finansowe, Ubezpieczenia”, 2016, nr 79, s. 57.

${ }_{35}$ A.M. Firek, Real Estate Crowdfunding - tłum jako alternatywne źródło finansowania nieruchomości, „Rynek - Społeczeństwo - Kultura”, 2017, nr 3 (24), s. 44.

${ }^{36}$ M. Gostkowska-Drzewicka, Crowdfunding jako źródło ..., op. cit. s. 57.

${ }^{37}$ A. M. Firek, Real Estate Crowdfunding ..., op. cit., s. 46.

${ }^{38}$ D. Kordela, Crowdfunding nieruchomości przykładem rozwoju finansowania społecznościowego, „Prace Naukowe Uniwersytetu Ekonomicznego we Wrocławiu”, 2017, nr 478, s. 251.

${ }^{39}$ Ibidem, s. 253. 
Obligacje korporacyjne mogą przybrać formę obligacji deweloperskich ${ }^{40}$. Deweloper emituje obligacje, określając warunki emisji, np.: oprocentowanie, częstotliwość wypłat odsetek. Najpierw następuje spłata odsetek w terminie zapadalności obligacji pożyczonego kapitału. Emisja obligacji deweloperów jest praktykowana od końca lat dziewięćdziesiątych XX wieku, jednak akcentuje się lata dziesiąte XXI wieku. Powstała bowiem specjalistyczna platforma w zakresie obrotu obligacjami nieskarbowymi - Catalyst ${ }^{41}$. Odtąd, oprócz tzw. niezorganizowanego rynku, funkcjonuje również giełdowy rynek dłużnych instrumentów finansowych ${ }^{42}$. Obligacje korporacyjne deweloperów mają wyższe oprocentowanie niż obligacje skarbowe ${ }^{43}$.

Project finance jest metodą finansowania inwestycji, szczególnie kapitałochłonnych, np. na rynku nieruchomości. Uwidacznia się jej zastosowanie w przypadku projektów deweloperskich, m.in. w odniesieniu do powierzchni, np.: handlowej, biurowej, przemysłowej, mieszkaniowej, rekreacyjnej, a także projektów aktywizujących zabytki. W jej zakresie powołuje się specjalny podmiot gospodarczy, tj. spółkę celową (SC), której działalność dotyczy realizacji konkretnego projektu, w tym zaciągnięcia kredytu w stosunku do przyszłych dochodów, jakie są planowane w przyszłości ${ }^{44}$.

W obszarze rynku leasingowego wyodrębnia się leasing nieruchomości ${ }^{45}$. Leasing jest specyficzną usługą finansową, umożliwiającą odpłatne korzystanie z określonego dobra przez konkretny okres wraz z ewentualnym wykupem. Wyróżnia się leasing operacyjny i finansowy ${ }^{46}$. Możliwe jest osiągnięcie korzyści podatkowych, np.: poprzez uznawanie rat leasingowych za koszt uzyskania przychodu ( $\mathrm{w}$ przypadku leasingu operacyjnego), skracanie amortyzacji (w odniesieniu do leasingu finansowego). Leasing nieruchomości w Polsce istnieje od około początku XXI wieku, ale w porównaniu z państwami zachodnimi osiąga dotąd niewielką skalę ${ }^{47}$.

Metoda buy-back odpowiada finansowaniu projektów inwestycyjnych o wymiarze deweloperskim w fazie przedinwestycyjnej. Celem jest osiągnięcie kapitału do przejścia do fazy inwestycyjnej projektu. Charakteryzuje ją szybki przebieg inwestycji, w tym zwrot. Na uwagę zasługuje zatem krótkoterminowa alokacja kapitału i ponadprzeciętna stopa zwrotu. W ramach transakcji buy-back

\footnotetext{
${ }^{40}$ H. Henzel, K. Śmietana, A. Maszczyk, Atrakcyjnośc inwestycyjna instrumentów finansowych na rynku nieruchomości w warunkach kryzysu, „Studia Ekonomiczne”, 2013, nr 155, s. 30.

${ }^{41}$ M. Gostkowska-Drzewicka, Obligacje w strukturze ..., op. cit. s. 96.

${ }^{42}$ E. Zagórska, L. Makowski, Zaangażowanie deweloperów ..., op. cit., s. 157.

${ }^{43}$ H. Henzel, K. Śmietana, A. Maszczyk, Atrakcyjność inwestycyjna ..., op. cit. s. 33.

${ }^{44}$ A. Wojewnik-Filipkowska, Project finance $w$ finansowaniu inwestycji $w$ nieruchomości - zalety i wady spótki celowej, „Świat Nieruchomości”, 2008, nr 4 (66), s. 10.

${ }^{45} \mathrm{~J}$. Gwizdała, Leasing jako alternatywne źródło finansowania inwestycji $w$ nieruchomości, „Zarządzanie i Finanse”, 2012, r. 10, cz. 1, s. 334.

${ }^{46}$ M. Okręglicka, Leasing jako ustuga finansowa na rynku nieruchomości w Polsce, „Prace Naukowe Uniwersytetu Ekonomicznego we Wrocławiu”, 2014, nr 355, s. 311.

${ }^{47}$ Ibidem, s. 312.
} 
przyznaje się inwestorowi udział w projekcie. Mechanizm ten jest stosowany np. na dubajskim rynku nieruchomości w zakresie nowoczesnych apartamentó $w^{48}$.

Timesharing polega na nabywaniu (sezonowego) prawa dotyczącego korzystania $\mathrm{z}$ nieruchomości $\mathrm{w}$ ustalonym czasie $\mathrm{w}$ roku (przez długość trwania umowy), w zamian za wkład pieniężny, w tym zryczałtowaną odpłatność dla właściciela nieruchomości przekraczającą przeciętny poziom dochodu z tradycyjnego wynajmu turystycznego. Określa się go jako tzw. własność wakacyjną. Często te nieruchomości są położone w ogrodzonych kompleksach, stąd prawo użytkowania niejednokrotnie jest poszerzane wobec przynależnej infrastruktury sportowej, rekreacyjnej (siłowni, kortów tenisowych, basenu, sauny) ${ }^{49}$. W Polsce timesharing zaczął rozwijać się dopiero od około lat 90. XX wieku, natomiast zagranicą od około lat 70. XX wieku (z wyróżnieniem np.: Hiszpanii, Wysp Kanaryjskich).

Przeprowadzona kwerenda bibliograficzna unaocznia determinanty wdrażania poszczególnych form finansowania inwestycji. W odniesieniu do uwarunkowań implementacji poszczególnych, alternatywnych źródeł finansowania projektów inwestycyjnych wyodrębnia się: zdolność kredytową inwestora, jego znajomość e-środowiska, formę prawną i kreatywność, etap podejmowanego procesu inwestycyjnego oraz rodzaj nieruchomości stanowiącej przedmiot inwestycji (w kontekście ich funkcji użytkowych).

\section{Podsumowanie}

Niniejsze badanie uwydatnia istotność kapitałochłonnego wymiaru inwestycji bezpośrednich na rynku nieruchomości, zwłaszcza lokalizowanych na terenach poprzemysłowych. Z punktu widzenia lokalnego podmiotu publicznego konieczne jest dokonywanie aktywizacji terenów poprzemysłowych. Ich specyficzne uwarunkowania stanowią jednak wyzwanie dla miast, $\mathrm{w}$ tym polskich. Jednocześnie podkreśla się ważność udziału sektora biznesu podejmującego ożywianie terenów poprzemysłowych, połączonego z osiąganiem wieloaspektowego wymiaru efektów. Nie każdy teren poprzemysłowy posiada na tyle wystarczający potencjał inwestycyjny, by skłonić sektor biznesu do realizowania szczególnie kapitałochłonnych projektów na jego obszarze. Tym bardziej wymagana jest dywersyfikacja źródeł finansowania inwestycji. Wśród tzw. nowoczesnych źródeł finansowania na rynku nieruchomości zidentyfikowano: crowdfunding, obligacje korporacyjne, project finance, leasing, metodę buy-back i timesharing. Są one alternatywami względem siebie, jak również wobec tradycyjnego kredytu hipotecznego. Ich implementacja zależy m.in. od: formy prawnej

\footnotetext{
${ }^{48}$ P. Oleksy, Buy-back na rynku nieruchomości - zarys problematyki, „Świat Nieruchomości”, 2009, nr 2(68), s. 46, 49.

${ }^{49}$ A. Banaszek, S. Banaszek, Timesharing jako źródło finansowania nieruchomości rekreacyjnych, "Journal of the Polish Real Estate Scientific Society", 2006, no. 14(1), s. 1.
} 
inwestora, rodzaju nieruchomości stanowiącej przedmiot inwestycji, etapu procesu inwestycyjnego.

W związku z kryzysogennymi uwarunkowaniami kształtowania terenów poprzemysłowych w przestrzeni miast, ich istotną rolą w odniesieniu do osiągania rozwoju lokalnego oraz rozwojowym charakterem nowoczesnych źródeł finansowania nieruchomości zagranicą, zaleca się analizowanie wdrażania alternatywnych źródeł finansowania projektów sektora biznesu, aktywizujących tereny poprzemysłowe w mieście. Może temu służyć zintensyfikowanie lokalizowania projektów sektora biznesu na terenach poprzemysłowych, których ożywianie będzie skuteczne wobec poszczególnych społeczności i opłacalne dla sektora biznesu.

\section{Literatura}

Adams D., de Sousa C., Brownfield Development: A Comparison of North American and British Approaches, "Urban Studies", 2010, no. 47.

Banaszek A., Banaszek S., Timesharing jako źródło finansowania nieruchomości rekreacyjnych, "Journal of the Polish Real Estate Scientific Society", 2006, no. 14 (1).

Barburski J., Kapitały własne jako podstawa bezpieczeństwa działalności gospodarczej na przyktadzie przedsiębiorstw WIG20, „Finanse, Rynki Finansowe, Ubezpieczenia”, 2014, nr 67.

Cellmer R., Spatial analysis of local real estate market activity - the example of the city of Olsztyn, [in:] Topical issues in the valuation and application of market value, Polish Real Estate Scientific Society, Olsztyn 2012.

Cobârzan B., Overview of financial and non-financial incentives for brownfield redevelopment, "Transylvanian Review of Administrative Sciences", 2008, no. 23.

Czechowska I.D., Finansowanie za pomoca kredytu bankowego wobec braku stabilności finansowej a problem bezpieczenstwa konsumenta, „Annales. Etyka w życiu gospodarczym", 2010, nr 13(1).

Drobniak A, Urban resilience - nowa perspektywa badawcza rozwoju miast, [w:] Badania miejskie i regionalne. Doświadczenia i perspektywy, F. Kuźnik (red.), „Studia KPZK PAN", 2013, t. 153.

Drobniak A., Urban resilience and post-industrial city, [in:] Urban resilience concept and post-industrial cities in Europe, A. Drobniak (ed.), University Economics in Katowice, Katowice 2014.

Enzimuo P.N., Onyeijaka C.J., Emoh F.J., Sources of real estate finance and their impact on property development in Nigeria: a case study of mortgage institutions in Lagos Metropolis, "British Journal of Environmental Research", 2014, vol. 2(2).

Firek A.M., Real Estate Crowdfunding - tłum jako alternatywne źródto finansowania nieruchomości, „Rynek - Społeczeństwo - Kultura”, 2017, nr 3(24).

Gasidło K., Przekształcenia terenów i obiektów poprzemystowych jako problem urbanistyczno-architektoniczny województwa ślaskiego, Zeszyty Naukowe Politechniki Śląskiej, nr 52, Gliwice 2013. 
Gasidło K., Przekształcenia terenów poprzemysłowych - efekty i perspektywy badań $i$ działań, „Problemy Ekologii”, 2008, nr 12(2).

Gostkowska-Drzewicka M., Crowdfunding jako źródło finansowania inwestycji w nieruchomości, „Finanse, Rynki Finansowe, Ubezpieczenia”, 2016, nr 79.

Gostkowska-Drzewicka M., Model funkcjonowania rynku deweloperskiego, „Zarządzanie i Finanse", 2012, r. 10, nr 2, cz. 1.

Gostkowska-Drzewicka M., Obligacje w strukturze kapitału przedsiębiorstw deweloperskich notowanych na GPW, „Finanse, Rynki Finansowe, Ubezpieczenia”, 2014, nr 65.

Grimski D., Ferber U., Urban Brownfields in Europe, "Land Contamination Reclamation", 2001, vol. 9(1).

Gwizdała J., Leasing jako alternatywne źródło finansowania inwestycji $w$ nieruchomości, „Zarządzanie i Finanse”, 2012, r. 10, cz. 1.

Henzel H., Śmietana K., Maszczyk A., Atrakcyjność inwestycyjna instrumentów finansowych na rynku nieruchomości w warunkach kryzysu, „Studia Ekonomiczne”, 2013, nr 155.

Janasz K., Kapitał jako podstawa rozwoju przedsiębiorstwa, „Studia i Prace Wydziału Nauk Ekonomicznych i Zarządzania", 2008, nr 1.

Kaczmarek S., Skuteczność procesu rewitalizacji. Uwarunkowania, mierniki, perspektywy, „Studia Miejskie”, 2015, nr 17.

Kordela D., Crowdfunding nieruchomości przykładem rozwoju finansowania społecznościowego, „Prace Naukowe Uniwersytetu Ekonomicznego we Wrocławiu”, 2017, nr 478.

Koutský J., Slach O., Boruta T., Restructuring Economies of Old Industrial Regions - Local Tradition, Global Trends In The Scale of Globalization. Think Globally, Act Locally, Change Individually in the 21st Century, University of Ostrava, Ostrava 2011.

Kraske R., Private Investment in Brownfield Redevelopment in the Greater Philadelphia Area: A Case-Study Analysis, "Master of Envionmental Studies Capstone Projects", 2007, no. 14

Kucharska-Stasiak E., Pomiar wartości na gruncie ekonomii- reperkusje dla wyceny nieruchomości, "Journal of the Polish Real Estate Scientific Society", 2011, nr 19(1).

Maciejewska A., Turek A., Rewitalizacja obszarów zurbanizowanych i poprzemysłowych jako kierunek zrównoważonego rozwoju miast, [w:] Gospodarka przestrzenna w świetle wymagań strategii zrównoważonego rozwoju, A. Maciejewska (red.), „Studia KPZK PAN", 2012, vol. 142.

Okreglicka M., Leasing jako ustuga finansowa na rynku nieruchomości $w$ Polsce, „Prace Naukowe Uniwersytetu Ekonomicznego we Wrocławiu”, 2014, nr 355.

Oleksy P., Buy-back na rynku nieruchomości - zarys problematyki, „Świat Nieruchomości”, 2009, nr 2 (68).

Sikorski D., Zmiany funkcjonalne terenów przemysłowych i poprzemysłowych we Wrocławiu po 1989 roku, [w:] Przekształcenia przestrzeni miejskiej Wroctawia. Ujęcie geograficzne, B. Namyślak, R. Szmytkie (red.), Wydawnictwo Uniwersytetu Wrocławskiego, Wrocław 2012.

Śmietana K., Idea odpowiedzialnych inwestycji $w$ nieruchomości $w$ działalności deweloperskiej, "Journal of Management and Finance", 2014, nr 12(4).

Sutton S.A., Urban Revitalization in the United States: Policies and Practices, Columbia University, 2008. 
Sztando A., Gospodarcza płaszczyzna programów rewitalizacji obszarów miejskich, „Studia Miejskie", 2010, t. 1.

The Future lies on Brownfields, Federal Environmental Agency, Dessau 2005.

The Management of Redevelopment. A Guidance Note, The World Bank, 2010.

Wink R., Regional Economic Resilience: Policy Experiences and Issues in Europe, "Raumforschung und Raumordnung", 2014, no. 72(2).

Wojewnik-Filipkowska A., Project finance $w$ finansowaniu inwestycji $w$ nieruchomości zalety i wady spółki celowej, „Świat Nieruchomości”, 2008, nr 4 (66).

Zagórska E., Makowski L., Zaangażowanie deweloperów $w$ proces zagospodarowania terenów poprzemysłowych, „Zarządzanie”, 2016, nr 24, t. 1. 